\title{
Meister Eckhart: Pandangan Teologisnya
}

\author{
Eduard Salvatore da Silva, a,1 \\ Eddy Kristiyanto ${ }^{\text {a,2 }}$ \\ Sekolah Tinggi Filsafat Driyarkara, Jakarta, Indonesia a \\ sdreduofm@gmail.com ${ }^{1}$ \\ aeddykristiyantoofm@gmail.com ${ }^{2}$
}

\section{Keywords:}

Allah,

Keallahan,

Manusia,

Teologi Mistik,

Pelepasan Diri,

Ada,

Ketiadaan,

Inteligensia Ilahi

\begin{abstract}
Meister Eckhart is a German philosopher, theologian, and mystician of the XIII-XIV century who has various important perspectives on the philosophical-theological (Human Being-God), spiritual and of course mystical concerning the unity of the soul with God through self-detachment. For Eckhart, Being is identical with God Himself as the only reality. All things outside God are nothingness. This figure was influential in his day, though not free from some excesses of his views that are considered controversial and make his teaching labeled as heresy by the authority of the Church. Nevertheless, his various philosophical-theological, and spiritual insights concerning the concept of Deity, especially in the mystical level, are very relevant to be experienced both in the context of theological studies and the development of spiritual life.
\end{abstract}

\section{PENGANTAR}

Perkembangan pemikiran Abad Pertengahan Eropa Barat, khususnya menyangkut Teologi Mistik, ${ }^{1}$ sebagai refleksi iman atas tindakan dan pengalaman, atau keadaan (jiwa) manusia menyangkut hubungannya dengan Yang Ilahi, sangatlah menarik. Refleksi iman ini mendalami berbagai bentuk

1 Sumber yang dimanfaatkan di sini a.I.: C. McColman, The Big Book of Christian Mysticism, (Charlottesville, VA: Hampton Roads, 2010); B. McGinn, The Essential Writings of Christian Mysticism, (New York: Randon House, 2006); M.A. Mclntosh, Mystical Theology: The Integrity of Spirituality and Theology, (Maldon-Oxford: Blackwell, 1998); B. McGinn, The Presense of God: A History of Western Christian Mysticism, 7 Vols., (New York: Crossroad, 1991-2017). doa yang luar biasa, bentuk permenungan yang lebih tinggi, wahyu pribadi, visi, yang menciptakan persatuan yang tumbuh antara (jiwa) manusia dengan Allah. Persatuan itu yang dikenal sebagai kesatuan mistik. ${ }^{2}$

Teologi Mistik bersifat eksperiensial dan memiliki pola tertentu, karena tidak hanya mengolah pengalaman jiwa (entah konsolasi entah desolasi) saja, tetapi juga menjelaskan

\footnotetext{
2 Kesatuan mistik ini antara lain dielaborasi oleh Evan B. Howard, "Mysticism", dalam Glen G. Scorgie, cs. (ed.), A Dictionary of Christian Spirituality, (Michigan: Zondervan, 2011), 179.
} 
pedoman dan bimbingan bagi orang yang mengalami momen tersebut. Pola yang demikian itu memiliki dasarnya pada autoritas Kitab Suci, ajaran para Bapa Gereja, penjelasan para teolog, serta praksis tradisi yang teruji dalam hidup mistik. ${ }^{3} \mathrm{Hal}$ ini dihayati sebagai satu bentuk kesempurnaan Kristen yang terkonfirmasi dengan praktik kebajikan dan kesalehan hidup.

Dalam sejarah mistisisme Kristen Barat, Meister Eckhart ( \pm 1260-1328) dihormati sebagai salah seorang tokoh terpenting yang berhasil merumuskan pengalaman spiritual, yang akhirnya menjadi salah satu tonggak, bahkan pilar teologi Abad Pertengahan. ${ }^{4}$ Berkenaan dengan ini, karya bersama ini hendak memberi tempat pada pengertian tentang mistisisme dengan latar pemikiran, riwayat hidup dan pokok terpenting pandangan Meister Eckhart, terutama teologi beliau, konsepnya mengenai ciptaan, relasi jiwa manusia dengan Allah, dosa dan penebusan, serta etika. Pada bagian akhir karya ini akan dikemukakan beberapa simpul serta tanggapan kritis yang relevan berkenaan dengan pokok ini.

\section{MISTIK, MISTISISME, DAN TEOLOGI MISTIK}

Istilah atau ungkapan mistik (Bhs. Yunani, mystikos), pada dasarnya senantiasa berhubungan dengan sikap rahasia. Sikap itu utamanya berkenaan dengan sifat ilahi.

3 Lihat A. de Sutter, "Mistica", dalam Dizionario Enciclopedico di Spiritualità/2. A cura di Ermanno Ancilli, (Roma: Città Nuova Editrice, 1990), hlm. 1625-1631.

4 Kebesaran Eckhart terbentang dalam penguasaan tradisi Dominikan, yang dipelihara dalam semangat keilmuan universiter, yang dipersubur dengan humus Agustinian yang neoplatonis, yang dipengaruhi oleh para bapak Gereja Yunani dan Albertus Magnus, tanpa kehilangan jati diri dalam mengembangkan mistik spekulatif. Hal ini membuat arus baru dalam teologi, yang dicurigai oleh para pejabat Gereja, bahkan oleh para dominikan sendiri. Lihat Alois Dempf. Meister Eckhart. Eine Einführung in sein Werk, (Leipzig, 1934); Joseph Bach. Meister Eckhart, der Vater der deutschen Spekulation, (Frankfurt a. M., 1964).
Mistik dipahami sebagai pengalaman keterbukaan manusia akan realitas ilahi, yang dimaknai oleh manusia dalam sebuah bentuk partisipasi unik akan Allah. Di dalam penggunaan tradisional kata mistik sering kali diimbuhi dengan aspek irasional atau adikodrati untuk lebih mendekatkan dengan sifat ilahi daripada manusiawi. Kata mistik, yang tidak digunakan dalam Kitab Suci, diperkenalkan dalam susastra Kristiani yang bercorak platonis dalam Sekolah Aleksandria. Dalam Perjanjian Baru, istilah mistik disambungrapatkan dengan kata misteri (Yunani

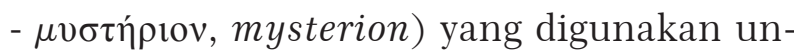
tuk memerikan pengalaman manusia akan Allah yang menyelamatkan. ${ }^{5}$ Misteri Allah yang tersembunyi bagi manusia (ciptaan) terungkap secara penuh dalam realitas Yesus Kristus (Yoh. 1; Fil. 2:7) sehingga dapat dialami manusia secara penuh. ${ }^{6}$

Salah seorang tokoh dalam Sekolah Aleksandria adalah Origenes (185-254), ${ }^{7}$ yang memperkenalkan metode tafsir Kitab Suci. Metode yang dimaksudkan adalah makna mistik. Dalam sejarah Ilmu Tafsir (Hermeneutika), metode yang mencari makna mistik dari pesan-pesan terdalam Kitab Suci disebut juga metode alegoris. ${ }^{8}$ Jadi, sekurang-kurangnya ada dua cara atau metode, pertama, memahami pengalaman (yang berhubungan dengan yang ilahi, transenden); kedua, menafsirkan Sabda Ilahi dalam Kitab Suci. Dengan kata lain, pengalaman akan Allah dapat berciri-corak mistik. Maksud-

$5 \quad$ Hal ini ditegaskan dalam Surat Paulus: "Kepada mereka Allah mau memberitahukan, betapa kaya dan mulianya rahasia itu di antara bangsa-bangsa lain, yaitu: Kristus ada di tengah-tengah kamu, Kristus yang adalah pengharapan akan kemuliaan!" (Kol. 1:27).

6 Evan B. Howard, "Mysticism", Gordon S. Wakefield (ed.). A Dictionary of Christian Spirituality, (Los Angeles: SCM Press Ltd., 1988), 179-180.

7 Lihat Henri Crouzel, Origen. Translated by A.S. Worrall. (Edinburgh: T.\&T. Clark, 1998).

8 Baca M. Simonetti, Biblical Interpretation in the Early Church. An Historical Introduction to Patristic Exegesis, (Transl. John A. Hughes. Edinburg: T\&T Clarck, 1994), 34-52. 
nya, manusia beriman dapat memiliki pengalaman persatuan dengan yang ilahi sehingga dalam dirinya pengalaman insani itu ditengarai melampaui pemaknaan historis, prinsip-prinsip filosofis dan moral dari pembacaan atas Kitab Suci. ${ }^{9}$ Pengalaman tersebut sedemikian intensif, khusus, mendalam (yang dapat disertai dengan ekstase dan kontemplasi). Di dalam mistisisme Kristiani meski terjadi persatuan antara manusia beriman (baca: seorang mistikus) dengan Allah, namun ada perbedaan antara manusia tersebut dengan Allah.

Sementara itu, Teologi Mistik merupakan refleksi orang beriman atas dua tataran yang berbeda, yaitu pemahaman dan teori mistis di satu pihak, dan pelbagai realitas yang mewujud dari kehidupan mistis di lain pihak. Kedua unsur itu diterangkan lebih lanjut oleh Thomas Merton dengan sangat gamblang,

"Without mysticism there is not real theology, and without theology there is no real mysticism. Hence the emphasis will be on mysticism as theology, to bring out clearly the mystical dimensions of our theology, hence to help us to do what we must really do: life our theology. Some think is is sufficient to come to the monastery to live the rule. More is required - we must live our theology, fully, deeply, in its totality. Without this, there is no sanctity. The separation of theology from "sprituality" is a disaster." 10

Dua unsur yang dinyatakan Thomas Merton tersebut dipandang sebagai satu kesatu-

$9 \quad$ Mistik Kristen: a.Refleksi makna mistis dari Kitab Suci b.Pemaknaan mistik dari sakramen-sakramen Kristiani cPengetahuan akan Allah dalam Wahyu Kristus yang dicerap berdasarkan pengungkapan misteri-Nya (Ef. 3:9). Bdk. Andrew Louth, "Mysticism", Gordon S. Wakefield (ed). A Dictionary of Christian Spirituality, (Los Angeles: SCM Press Ltd., 1988), 272.

10 Thomas Merton, A Course in Christian Mysticism, (Collegeville, MN.: Liturgical Press, 2017), 1. an yang paripurna. Dalam pembacaan kami, itulah sebabnya mengapa St. Yohanes Salib menyatakan bahwa teologi mistik Kristen itu the science of love (ciencia de amor) ${ }^{11}$ atau meminjam istilah Bernard Lonergan, teologi mistik itu being in love with God. ${ }^{12}$ Tidak berlebihan kiranya jika pokok pembicaraan tentang Teologi Mistik dalam ranah kristianitas dinyatakan pula sebagai jantung teologi dan sentrum kekristenan. ${ }^{13}$ Sosok Meister Eckhart yang menjadi fokus penelitian ini berkiprah dalam tiga terminologi: mistik, mistisisme, dan teologi mistik dengan satu jiwa yang sama, yaitu iman Kristiani, yang menumbukan keyakinan bahwa Allah tidak melihat yang manusia lakukan, tetapi melihat cinta, kebaktian, dan kehendak di dalam nurani, di balik perbuatan itu. ${ }^{14}$

\section{MEISTER ECKHART}

\section{Riwayat Hidup}

Yohanes Eckhart von Hochheim, lahir di Hochheim, Landgraviate-Thuringia, Jerman $^{15}$ pada 1260 dan wafat pada 1327/1328

11 Mengutip kata-kata St. Yohanes Salib ini, kami memanfaatkan karya dan analisis Daniel A. Dombrowski, St. John of the Cross: An Appreciation, (New York: State University of New York Press, 1992), 95-98.

12 Dipungut dari Tad Dunne, "Being In Love", Method: Journal of Lonergan Studies 13/2 (Fall 1995): 161-175 yang mengolah pandangan Bernard Lonergan, terutama dalam karyanya Method In Theology (1972). Pandangan Yohanes Salib (catatan kaki no. 11 di atas) dan Lonergan tentang Being In Love With God menginspirasi William Johnston, Mystical Theology. The Science of Love, (New York: Orbis Books, 1998) yang mengedepankan gagasan tentang bagaimana mistisisme Kristen kini seharusnya berdialog dengan ilmu pengetahuan modern dan agama-agama Timur, peduli pada keadilan sosial, masalah seksualitas, perdamaian mondial, dan penyelamatan lingkungan hidup.

13 Penelitian dan studi lengkap tentang teologi mistik dalam kekristenan dapat dibaca di Edward Howells - Mark A. McIntosh (eds.), The Oxford Handbook of Mystical Theology, (Oxford: Oxford University Press, 2020).

14 Meister Eckhart, Talks of Instruction XVI, dalam James M. Clark, cs (Transl.), Meister Eckhart: Selected Treatise and Sermons, (London: HarperCollins Publisher, 1994), 67-68.

15 Beberapa sumber tentang Eckhart a.I. Maurice O'C. Walshe (Translator), The Complete Mystical Works of Meister Eckhart. With Foreword by Bernard McGinn. (New York: Crossroad, 2009); Bernard McGinn, The Mystical Thought of Meister Eckhart: The Man from Whom God Hid Nothing, (New York: The Crossroad Publishing Company, 2001); Matthew Fox, Meister 
di Avignon, Perancis. Ia dikenal sebagai seorang filsuf-teolog Ordo Dominikan (Ordo Predicatorum) serta penulis spiritual yang disebut-sebut sebagai "mistikus spekulatif"16 terbesar Jerman. Dalam sejumlah karyanya yang ditulis dalam bahasa Jerman dan Latin, ${ }^{17}$ ia juga merumuskan wacana mengenai "kesatuan mistik", yakni kelahiran Sabda ilahi dalam jiwa manusia. Pada dasar visi spekulatif ini ia letakkan afinitas metafisis antara Allah dan jiwa.

Pada usia delapan belas tahun, Eckhart bergabung dalam Ordo Dominikan ${ }^{18}$ dan menjalani studi universiternya (filsafat dan teologi) di Köln, Jerman, di bawah bimbingan teolog Skolastik ternama, Albertus Agung. Sebagai Dominikan, pemikiran Eckhart juga tidak dapat dilepaskan dari pengaruh Thomas Aquinas yang wafat beberapa tahun setelah Eckhart bergabung dalam Ordo. ${ }^{19}$ Kendati demikian pengaruh pemikiran Thomas ini bertransformasi di fase selanjutnya ketika Eckhart merumuskan pandangannya sendiri. Eckhart ditahbiskan menjadi imam pada 1293 dan kemudian ditugaskan sebagai Vikaris Dominikan di Erfurt, Thuringia (Jerman, 1294). Sebelum dan sesudah menjalani tugas tersebut, ia mengajar Teologi di Universitas St. Jacques, Paris yang juga menjadi tempat beliau meneri-

Eckhart: A Mystic Warrior for Our Time, (Novato, CA.: New World Library, 2014).

16 Di sini bacaan kami mengacu pada G. Della Volpe, II misticisme speculativo di Maestro Eckhart nei suoi rapporti storici, (Bologna: il Mulino, cetak ulang 1989).

17 Karya lengkap Eckhart sudah diterjemahkan ke dalam Bahasa Inggris oleh M. O'C. Walshe. Dalam traktat dan khotbah populer ia memperkenalkan refleksi yang lebih pribadi, dan karyakarya yang dianggap "mistik" tentang pelbagai tema seperti kemiskinan roh, kelahiran Kristus dalam jiwa.

18 Ordo Predicatorum (OP) didirikan di selatan Prancis pada 1215 oleh St. Dominikus (1170-1221). Para Dominikan secara khusus dididik untuk menjadi pengajar utama Gereja menyangkut berbagai pokok iman. Bdk. New World Encyclopedia, "Dominican Order" dalam http://www.newworldencyclopedia. org/ entry/Dominican_Order diunduh pada 4 Maret 2018, pk. 21. 22 WIB.

19 Lihat Anastasia Wendlinder, Speaking of God in Thomas Aquinas and Meister Eckhart: Beyond Analogy, (Ashgate Publishing, 2014). ma predikat Master/Meister (1302) setelah membuat komentar atas karya Petrus Lombardus (The Sentences - teks utama Abad Pertengahan yang menjadi prasyarat dalam studi teologi saat itu). ${ }^{20}$ Sejak saat itu, sosok ini dikenal dengan sebutan Meister/Master Eckhart sebagai gelar bergengsi bagi pengajar teologi di masa itu.

Meister Eckhart menjabat sebagai Provinsial pertama di provinsi baru Dominikan di Saxony (yang meliputi wilayah Belanda hingga Livonia di Baltik, termasuk Thuringia, Jerman), Vikaris di Bohemia (wilayah Ceko dan sekitarnya pada 1306 hingga pada 1311) juga mendirikan beberapa komunitas (suster) baru. Pada 1311, Eckhart kembali ditugaskan untuk menjadi provinsial di Teutonia (Freiburg-Jerman) sekaligus meneruskan karir profesionalnya di bidang teologi. Selanjutnya, ia tinggal di Strasburg (Jerman-Prancis), sebagai profesor teologi, direktur spiritual dan pengkhotbah (1313) sebelum menjadi Vikaris General Dominikan setahun setelahnya. Selain itu, salah satu karya penting yang dijalankan Eckhart adalah berkhotbah dan menjadi pembimbing rohani bagi para Dominikan sendiri ${ }^{21}$ maupun para suster kontemplatif di wilayah perbukitan Sungai Rhein, Jerman.

Eckhart berkarya di Thuringia, Saxony dan Bohemia juga sebagai pembimbing rohani bagi para suster Dominikan dan Pergerakan Beguine sebagai bentuk hidup kontemplatif bagi para perempuan awam. ${ }^{22}$

20 Lihat Philipp W. Rosemann, The Story of A Great Medieval Book Peter Lombard's Sentences, (Toronto: University of Toronto Press, 2007.

21 Bernard McGinn (ed.), Meister Eckhart: The Essential Sermons, Commentaries, Treatises and Defence, (New York: Paulist Press, 1981), 10.

22 Studi mendalam tentang gerakan Beguine dilakukan antara lain oleh Herbert Grundmann, Religiöse Bewegungen im Mittelalter. Untersuchungen über die geschichtlichen Zusammenhänge zwischen der Ketzerei, den Bettelorden und der religiösen Frauenbewegung im 12. und 13. Jahrhundert und über die geschichtlichen Grundlagen der Deutschen Mystik, (Darmstadt: Wissenschaftliche Buchgesellschaft, 1977); Lausa 
Kelompok awam yang selibat baik laki-laki maupun perempuan ini tidak berafiliasi dengan tarekat Dominikan. Mereka mengambil bentuk hidup tanpa profesi religius yang permanen dan menjalankan Regula St. Agustinus, menopang kehidupan dengan kerja tangan dan berinteraksi dengan dunia, walau menjalankan selibat dengan penuh kebebasan, kemandirian ekonomi, dan kreativitas rohani. Kelompok yang berkembang pada awal abad ke-13 ini dimotivasi dan disemangati oleh praktik hidup para mistikus, seperti Mechtild Magdeburg (1210-90), Hadewijch Antwerp (1210-1260), dan Gertrude Helfta (1256-1301). ${ }^{23}$ Ada kelompok Beguine yang menjalankan praktik mistis yang kemudian dianggap sesat oleh Gereja, yakni Kelompok Roh Bebas (Free Spirit). ${ }^{24}$ Dalam sekte ini, diajarkan, jiwa yang berada dalam persatuan ilahi terbebas dari moralitas konvensional. Akhirnya, kelompok Beguines ini dituduh sebagai heresi sejak 1310 ketika Marguerite Porete dibakar hidup-hidup di tiang pancang Paris karena karyanya Miroir des Simples Ămes yang dinilai menyesatkan. ${ }^{25}$

Sepanjang hidupnya, Eckhart menulis berbagai komentar atas Kitab Suci, khususnya Kitab Kejadian, Keluaran, Kebijaksanaan, Pengkhotbah dan Injil Yohanes, yang kini sudah diterjemahkan. ${ }^{26}$ Selain itu, ia setidak-

Swan, The Wisdom of the Beguines: The Forgotten Story of $A$ Medieval Women's Movement, (New York: BlueBrigde, 2016).

23 Eckhart mempunyai hubungan rohani dengan para tokoh perempuan ini. Lihat studi B. McGinn, Meister Eckhardt and the Beguine Mystics: Hadewijch of Brabant, Mechthild of Magdeburg, and Marguerite Porete, (New York: Continuum, 2001).

24 Lihat Robert E. Lerner, The Heresy of the Free Spirit in the Later Middle Ages, (Berkeley: University of California, 1972).

25 Untuk artikel ini kami membaca buku terjemahannya, Mirror of Simple Souls/Marguerite Porete. Translated and Introduced by Ellen L. Babinsky. Preface by Robert E. Lerner. (Mahwah, New Jersey: Paulust Press, 1993); lihat pula Timothy Conway, "Meister Eckhart (1260-c1328): Nondual Christian Mystic Sage", dalam http://www.enlightened-spirituality.org/Meister_Eckhart.html, diunduh pada 1 Maret 2018, pk. 16.30 WIB.

26 Lihat Maurice O'C. Walshe (Transl.), The Complete Mystical Works of Meister Eckhart. With Foreword by Bernard McGinn. (New York: Crossroad, 2009). nya menulis empat karya besar yang disebut Risalah (Treatises). Dalam Talks of Instruction (1294), diuraikan pemikiran Eckhart menyangkut penyangkalan diri, keluhuran kehendak dan intelek serta ketaatan kepada Allah. Karya terbaiknya, Book of Divine Consolation didedikasikan untuk Ratu Hungaria, disusul The Nobleman dan On Detachment.

Pada usia 66 tahun, Eckhart dinilai oleh Heinrich von Virneburg, Uskup Agung Köln, sebagai tenaga pengajar dan gembala umat yang ajarannya sesat, bersimpati pada gerakan Beguines (yang dicap sebagai heresi), dan keyakinannya mirip dengan prinsip-prinsip Kelompok Roh Bebas (Fratelli del Libero Spirito). Dewan Kuria yang dibentuk Uskup itu menilai bahwa ada 150 butir yang dicurigai dapat menyesatkan umat. Bahkan kecurigaan itu juga berpengaruh pada keputusan Kapitel Umum Ordo Dominikan yang berlangsung di Venetia pada Musim Semi 1325. Sampai-sampai Kapitel itu berseru terhadap: "Para Saudara di Jerman yang mengajarkan dan mengatakan hal-hal di dalam khotbah-khotbahnya yang dapat dengan mudah mengantar umat yang sederhana dan kurang terdidik jatuh ke dalam kesalahan...,,,,," Memang, Kapitel tidak terang-terangan menyebutkan nama Eckhart, tetapi suasana dan arahnya sudah sangat jelas. Kecurigaan Kuria Keuskupan Agung Köln dan seruan yang mengarah pada Eckhart terutama berakar pada pokok pikiran Eckhart: Allah menyukai jiwa-jiwa dan bukan karya-karya lahiriah. Sebab itu tindakan-tindakan lahiriah samasekali tidak ada gunanya. ${ }^{27}$ Ungkapan Eckhart dibahasakan begini,

27 Laporan Uskup Agung Köln kepada takhta suci, yang waktu itu berada di Avignon, membuka pintu bagi tugas komisi untuk menyelidiki kasus Eckhart. Dari 150 butir yang kesalahan yang dituduhkan, komisi menemukan 28 butir kesesatan. Lihat F. Pelster, "Ein Gutachten aus dem Eckhart-Prozess in Avignon". Dalam Aus der Geisteswelt des Mittelalters. Festgabe Martin Grabmann. (Beitrage Suppement III), Münster 1935, SS. 1099-1124. 
"All things are God; God is all things. God may not understand himself without me. Before there were creatures, God was not God." 28

"In dumb creation there is something of God, but in the human soul there is God divine. The eye with which I see God is the same eye with which God sees me. My eye and God's eye are one eye."

"The highest that the spirit may attain in this mortal clay is this: to live in such a manner that virtue is no longer an effort, that is, that all virtues have become so natural to the soul that it not only purposely practises virtue, but makes all virtues shine forth from itself unconsciously, even as though it were virtue itself." ${ }^{29}$

Kutipan-kutipan tersebut dalam perspektif mistik dapat ditafsirkan bahwa teologi Eckhart berdasar pada prinsip kesatuan mistik antara jiwa (insani) dengan Allah, dan para lawan Eckhart melihat peluang untuk memandangnya sebagai panteis murni. Berbagai dugaan itu akan dicoba dipertanggungjawabkan oleh Eckhart di hadapan pengadilan kepausan di Avignon, Perancis. Ungkapan hati terdalamnya menyatakan maksudnya yang tak menghendaki kesesatan: They think that everything they don't' understand is an error and that every error is a heresy, when only obstinate adherence to error makes heresy and a heretic. ${ }^{30}$

Dalam perjalanannya menuju Avignon untuk mempertanggungjawabkan pandan-

28 Dikutip langsung dari Kuno Francke, "Medieval German Mys ticism". Dalam The Harvard Theological Rieview, Vol. 9, No. 1 (Jan., 1912): 111.

29 Kuno Francke, "Medieval German Mysticism". The Harvard Theological Rieview, Vol. 9, No. 1 (Jan., 1912): 112.

30 Hal ini diungkapkannya dalam Meister Eckhart (McGinn Translation), Defense dari Sermons 75, dalam Rik Van Nieuwenhove, An Introduction to Medieval Theology, (Cambridge: Cambridge University Press, 2012), 265. gannya di hadapan Paus, Eckhart meninggal dunia (1327/1328). ${ }^{31}$ Hal itu terjadi beberapa waktu sebelum Paus Yohanes XXII mengeluarkan Bulla In agro dominico, 27 Maret 1329, yang mengutuk 17 butir dalil Eckhart yang dinyatakan menyesatkan (heretik), dan 11 dalil dinyatakan dicurigai "sebagai dapat menyesatkan". Para penerus Eckhart, misalnya Heinrich Suso, Johannes Tauler tetap mempertahankan dan menyebarluaskan ajarannya secara moderat. ${ }^{32}$ Eckhart dikenal sebagai pelopor der deutsche Mystik (mistik Jerman), karena beliau memulai "Sekolah", yang menggerakkan pemikiran dan praksis menggereja, khususnya sebelum era Martin Luther. ${ }^{33}$

\section{Pokok Pandangan Meister Eckhart}

Meister Echkart memiliki beberapa pokok pandangan dalam khazanah Teologi Abad Pertengahan. Selain mengadopsi pandangan Neoplatonis, ia juga memberikan pandangan khas Kristiani yang amat alkitabiah dan pandangan seperti Dionysius Areopagite, Yohanes Scotus Eriugena. Tokoh-tokoh ini memengaruhi pengembangan pandangan Eckhart.

Dionysius Areopagite, seorang rahib Syria, menghasilkan karya fundamental tentang "jalan naik" menuju Allah dengan menggunakan simbol, ritual, dan tata laku tertentu menjadi salah satu inspirator Eck-

31 Asumsi umum para ahli menyatakan bahwa Eckhart meninggal 28 Jan. 1328 walau ada pandangan lain yang menyatakan Eckhart masih hidup dan berkarya beberapa waktu sebagai "anonim" sehubungan dengan tuduhan heresi yang sudah disematkan padanya. B. McGinn (ed.), Meister Eckhart, 17.

32 Bersama Ekhart, Heinrich Suso dan Johannes Tauler (serta Jan Ruysbroek) disebut mistik Jerman. Istilah lain yang populer Mistik Rheine mengingat gerakan itu berkembang di sepanjang sungai Rheine. Mereka meneruskan pemikiran Eckhart dengan cara yang moderat dan lebih mudah diterima daripada Eckhart.

33 Bdk. Eddy Kristiyanto, Reformasi dari Dalam. Sejarah Gereja Zaman Modern, (Yogyakarta: Kanisius, 2004), 49-50. Lebih lanjut, mistik Jerman (mistik Rhein) nantinya dipakai sebagai gerakan rohani yang memengaruhi reformasi Protestan. Baca A. Eddy Kristiyanto cs, Martin Luther: Musa Jerman. 5 Abad Reformasi Agama, (Jakarta: OBOR-BPK Gunung Mulia, 2017). 
hart. Ia juga menjadi salah seorang pelopor pendekatan Teologi Negatif ${ }^{34}$ yang menolak semua bentuk "dogma" tentang Allah dan membiarkan pengetahuan akan Allah ditangkap dalam pengalaman "kegelapan dari ketidaktahuan". ${ }^{35}$ Beberapa asas mistisisme Neo-Plantonis Kristen diperkenalkan di dunia Barat oleh Dionysius Areopagita, yang kemudian dilanjutkan oleh Yohanes Scotus Eriugena dalam karya Periphysion. ${ }^{36}$ Akhirnya, Hugo dan Richard St. Viktor menjadi figur skolastik yang juga menegaskan pentingnya dimensi dan pendekatan teologi mistik dalam khazanah Teologi Abad Pertengahan. ${ }^{37}$

Pandangan Meister Eckhart sendiri ditempatkan dalam konsep Mistisisme Dasar (mysticism of the ground) mengingat pandangannya yang menyatakan, "Dasar Allah adalah (identik) dasar jiwa (manusia)”, begitu juga sebaliknya. Dari sekian banyak alam pikiran, disinyalir bahwa pandangan Dionysius Areopagite dan Yohanes Scotus Eriugena (Neoplatonis) berpengaruh kuat pada pandangannya. ${ }^{38}$ Salah satu bentuk konkret

34 Lihat Bruce Milem, The Unspoken Word: Negative Theology in Meister Eckhart's German Sermons, (Washington, D.C.: the Catholic University of America Press, 2002).

35 Lihat I.P. Sheldon-Williams (ed.), Johannis Scotti Eurigenae Periphysion: De divisione naturae. 3 Vol. (Dublin: Dublin Institute for Advanced Studies, 1968-1981); Clarence E. Rolt, Dionysius the Areopagite On the Divine Names and the Mysticall Theology, (New York: Casimo Classics, 2007); Eric D. Perl, Theophany: The Neoplatonic Philosophy of Dionysius the Areopagite, (New York: State University of New York Press, 2007).

36 Perspektif ini dikembangkan di periode selanjutnya dalam pemahaman Teologi Apofatis (yang diperlawankan dengan Teologi Katafatis), sebagai metode berteologi untuk mendekati dan "mendeskripsikan" Allah dengan penyangkalan (negation). Pokok ini disarikan dari Andrew Louth, "Apophatic and Cataphatic Theology", dalam Amy Hollywood (ed.). Christian Mysticism, (New York: Cambridge University Press, 2012), 137-146.

37 Lihat The Didascalion of Hugh of Saint Victor: A Medieval Guide to the Art. Translated from the Latin with an introduction and notes by Jerome Taylor, (New York: Columbia University Press, 1991).

38 Pengaruh kuat itu diperlihatkan oleh Elisa Robino, "PseudoDionysius the Areopagite and Eckhart", dalam Jeremiah M. Hackett (ed), A Companion to Meister Eckhart, (Leiden-Boston: Brill, 2013), 299-309, khususnya 300-303; juga Willemien Otten - Geneviève Lachance, "The Language of the Mystical Embrace: Desire and the body in Johannes Scotus Eriugena and Meister Eckhart", dalam Les Études Philosophiques 2013/1 (No. 104): 121-141. adalah bagaimana Meister Eckhart berusaha mencapai sintesis antara pemikiran Yunani (kuno) dengan Kristen, terutama ketika Eropa tengah mengalami evaluasi intelektual sebagai tahap yang perlu dilalui untuk merumuskan sendiri jati diri Kekristenan. Dengan retorika yang agung, Eckhart mengkombinasikan konsep neoplatonis tentang "Oneness" -yang memuat gagasan bahwa prinsip dari Semesta ini adalah satu dan tidak terbagi- dengan kepercayaan Kristen tentang Trinitas. Lalu, bagaimana memerikan Allah Yang Mahasempurna melalui medium berupa bahasa yang tidak sempurna dan serba terbatas? Bagaimana dengan pandangan mistiknya, Eckhart "menggaulkan" filsafat dengan agama melalui keaslian hidup yang dialami dengan passion metafisis? Jawaban Eckhart atas soal-soal itu dijabarkan dalam sekian banyak karyanya yang nota bene tidak mudah dimengerti. ${ }^{39}$ Sebagai seorang penasihat spiritual, ajaran pokok Eckhart terdapat dalam khotbah-khotbahnya yang unik dan praktis dalam bahasa setempat, untuk membimbing umat, juga khususnya biarawan dan biarawati. Inti ajaran transformasi spiritual dan psikologis Alkitabiah-nya berkaitan dengan kekuatan kreatif yang ada dalam suatu ketiadaan hasrat dan pelepasan diri (dispassion and detachment) ${ }^{40}$ demi mencapai kesatuan jiwa (manusia) dengan Allah.

Kata kunci detachment (atau Abegeschiedenheit) yang berarti: pelepasan diri, pembebasan diri merujuk pada kondisi roh (jiwa). Kondisi tentang roh yang lepas itu tercapai manakala roh sendiri tetap ting-

39 Karya Meister Eckhart: 97 khotbah (berbahasa Jerman \pm 86 yang autentik), 4 karya Treatise dan 1 fragmen khotbah persiapan karya Opus Tripartitum (Jerman) dan 4 Legenda Eckhart. Bdk. Maurice O'C. Walshe (Transl.). The Complete Mystical Works of Meister Eckhart, (New York: A Herder \& Herder Book, 2009).

40 Uraian lebih lanjut dapat disimak dalam Margaret R. Miles, "Detachment" Gordon S. Wakefield (ed.), A Dictionary of Christian Spirituality, (Los Angeles: SCM Press Ltd. 1988), 111. 
gal "bergeming di hadapan semua hal yang membawa pada sukacita dan penderitaan, besar hati, bangga, rasa terpecah belah dan hancur, seperti sebuah gunung timah yang tidak bergerak sedikit pun oleh terpaan angin lembut yang berhembus." Berikut ini kami sampaikan beberapa khazanah ajaran Eckhart.

\section{Pandangan Eckhart Mengenai Allah}

Eckhart menyadari kerinduan terbesar manusia adalah persatuan jiwa dengan Allah sehingga pengetahuan manusia tentang Allah dan hubungannya dengan dunia amat diperlukan. ${ }^{41}$ Eckhart tidak meragukan, pengetahuan semacam itu diberikan dalam kepercayaan tradisional Gereja, namun dirasa tidak cukup bagi orang yang merindukan keselamatan, karena juga perlu dicapai dengan pengertian personal. Oleh karena itu, Eckhart "melangkah lebih jauh" dibandingkan apa yang dijalankan oleh tokoh mistik lain, seperti Hugo St. Victor. DIA (yang tertinggi) haruslah independen (tidak distrukturkan sebagai "Allah" tertentu oleh pihak manapun).

Dalam visi teologi Eckhart, Allah bersifat "subur". Ia "melahirkan" Putra, Sabda yang ada di dalam manusia dalam kepenuhan cinta-Nya karena Hasrat Roh Kudus (dimensi Trinitaris). Pokok ini berhubungan dengan ide Neoplatonik tentang kelimpahan/kemeluapan (ebullience; boiling over) dari yang Satu. ${ }^{42}$ Pemikiran ini juga diinspirasikan oleh gagasan Pseudo-Dionysius dan Yohanes Scotus Eriugena tentang kodrat ila-

41 Manusia berupaya menangkap dan mengetahui siapa yang ilahi itu. Tentang Dia, manusia memakai ungkapan paling tinggi dan paling hakiki yang mungkin. Kiranya dengan cara pandang demikian, Eckhart terbilang dalam kelompok yang memandang Allah dengan pengetahuan yang non-dualisme. Lihat C.F. Kelley, Meister Eckhart on Divine Knowledge, (New Haven-London: Yale University Press, 1977).

42 Bdk. Richard Woods, "Meister Eckhart and the Neoplatonic Heritage: the Thinker's Way to God." Dalam The Thomist: A Speculative Quarterly Review, Vol 54, (N. 4, Oct. 1990): 609639. hi. Eckhart merefleksikan bahwa "gerakan" itu tidaklah niscaya, tetapi sebagai suatu aksi bebas dari esensi ilahi yang "keluar". ${ }^{43}$

Realitas ilahi yang ditangkap ini bukanlah "Allah Teologi" atau "Allah Rumusan" atau "Allah Dogma" yang diterima begitu saja. Bagi "Sekolah” Teologi Mistik Eckhart, itulah Allah. Allah Yang Negatif, terutama bukan "Allah Teologi", "Allah Dogma". Dengan demikian, Eckhart melakukan distingsi antara Allah dan Keallahan (Deity yang disebut Gottheit - Jerman; God dan Godhead, Godhood - Inggris, state of being God). Distingsi ini penting, karena tidak ada predikat apapun dalam struktur being (yang terbatas) yang cocok disematkan pada Deity tadi. Eckhart merumuskan pandanganya demikian:

Have we spoken anything worthy of God? Rather I feel that I have done nothing but wish to speak: If I have spoken, I have not said what I wish to said. Whence do I know this, except because God is ineffable? If what I said were ineffable, it would not be said. And for this reason God should not be said to be ineffable, for when this is said something is said. (Contradictio in terminis). This contradiction is to be passed over in silence rather than resolved verbally. For God, although nothing worthy may be spoken of him, has accepted the tribute of human voice and wished us to take joy and praising him with our words. ${ }^{44}$

Négasi atas predikasi Allah di sini tidak hendak menyatakan, Allah dipahami sebagai ketiadaan dan kekosongan (nothingness dan

\footnotetext{
43 "Tertio ostendo quod non ita videtur mihi modo, ut quia sit, ideo intelligat, sed quia intelligit, ideo est, ita quod deus est intellectus et intelligere et est ipsum intelligere fundamentum ipsius esse." Quaestio Parisiensis I. n. 4; LWV, 40, 5-7. Intinya, Allah itu intellectus et intelligere.

44 Bernard McGinn (ed.), Introduction: Meister Eckhart Teacher and Preacher, (New Jersey: Paulist Press, 1986), 15.
} 
emptiness). Keallahan (Deity) adalah négasi dari being yang terbatas, tapi juga bukan non-being belaka (negation of negation), melainkan kepenuhan mutlak dari Ada (the absolute fulness of being). Singkatnya, ketika "distrukturkan" Allah tidak lagi "menjadi Allah". Manusia dapat "menemukan” Allah dalam jiwa mistik.

Eckhart memang sangat menekankan perbedaan antara the Unmanifest dan Manifest Absolute, ${ }^{45}$ dan pandangan Eckhart ini mengilhami gerakan Mistik Rhein, yang berkembang di lembah Sungai Rhein. Gerakan ini menerima bentuk-bentuk lain pujian kepada Allah, namun khususnya melalui jalan negatif dan penyangkalan (via negativa) dengan menolak segala indentifikasi kedirian dengan melepaskan segala bentuk kelekatan (gambaran, bentuk dan konsep) hingga tidak tersisa apapun kecuali Allah. Dalam situasi tersebut, jiwa mati di dalam segala dan hidup hanya di dalam Allah, Sang Ada Sejati. ${ }^{46}$

How is man to work together with God? Reduce self to nothingness! Still, this annihilation or diminution of self never gets so far that if God did not finish it in Himself, it would be imperfect.... The highest heights of [spiritual] exaltation lie precisely in the lowest depths of humiliation.... Therefore, the more humble a man may be, the more exalted he will be. ${ }^{47}$

Sebagai seorang mistikus, Eckhart juga teolog yang memiliki pandangan khas ten-

45 Uraian lebih lanjut mengenai pokok ini dapat disimak di Peter Russell, "The Manifest and the Unmanifest" dalam http:// www.peterrussell.com/Reality/RHTML/R28.php diunduh pada 5 Maret 2018, pk. 21.30 WIB.

46 Timothy Conway, "Meister Eckhart (1260-c.1328): Nondual Christian Mystic Sage" dalam http://www.enlightened-spirituality.org/Meister_Eckhart .html, diunduh pada 1 Maret 2018, pk. 16.30 WIB

47 Meister Eckhart, Talks of Instruction XXIII, James M. Clark, cs. (Penerj.), Meister, 83-89. tang Trinitas. ${ }^{48}$ Kehadiran Allah memang dipahami tidak berkualifikasi, kodrat yang tidak kodrati, namun tetap memanifestasikan dirinya dalam sifat alami tiga pribadi. Trinitas adalah manifestasi dari Deity. Dengan demikian, Eckhart melihat Bapa sebagai genesis (awal mula atau asal muasal); Keilahian sejati selalu ada dalam dirinya sendiri. Penyataan diri Allah ini menunjuk situasi penalaran, pembicaraan, dan sikap. Bapa sajalah yang memproklamasikan $\mathrm{Pu}$ tra, karena Bapa adalah Bapa hanya melalui Putra; serta Putra dalam segala hal adalah seperti Bapa. Inti dari Bapa juga adalah milik Putra, yakni keilahian. Dari sukacita dan cinta kasih, yakni Roh Kudus, keduanya saling memiliki satu sama lain. Eckhart melihat, dinamika Allah Trinitas tidak boleh dianggap berlangsung secara temporal belaka, namun sebagai proses terus-menerus dalam kekekalan. Dalam tafsiran para pembaca Eckhart, khususnya dalam diri Ray L. Hart, distingsi antara Deity (deitas) dan God dapat dipahami dalam pengertian potensi dan aktualitas. ${ }^{49}$

\section{Relasi Allah dan Ciptaan}

Manifestasi diri Allah dalam Trinitas diikuti oleh manifestasi-Nya dalam ciptaan. Segala sesuatu ada dalam keberadaan abadi Allah, walaupun esensi Allah tidak sepenuhnya termanifestasi. Eckhart memandang, ciptaan tidak memiliki pra-eksistensi ideal seperti yang ada di dalam Allah, yakni esensi konseptual yang datang dari intelegensi ilahi. Eksistensi ciptaan asing

48 Lihat B. McGinn, "The Dynamism of the Trinity in Bonaventure and Eckhart", dalam Franciscan Studies, 65 (2007):137-155; P. L. Reynolds, "Bullitio and the God beyond God: Meister Eckhart's Trinitarian Theology. Part I: The Inner Life of God", New Blackfriars, 70, N. 826 (April 1989): 169-181; P. L. Reynolds, "Bullitio" and the God beyond God: Meister Eckhart's Trinitarian Theology. Part II: Distinctionless Godhead and Trinitarian God," dalam New Blackfriars, 70, N. 827 (May 1989): 235-244;

49 Lihat Ray L. Hart, God Being Nothing: Toward a Theogony, (Chicago and London: The University of Chicago Press, 2016, 128. 
(diterima dari Ada yang ilahi), bukanlah entitas sejati tetapi (hanya) imanensi-Nya. Jadi, ciptaan (an sich) merupakan ketiadaan belaka. Ketika Allah tidak memanifestasikan diri-Nya, ciptaan juga tak ada. Ciptaan "terkurung" dalam batasan-batasan, yakni ruang dan waktu.

Namun di sisi lain, setiap ciptaan yang senantiasa bersatu dengan Entitas Sejatinya (Allah) yang bersifat abadi. ${ }^{50}$ Di sini coba dilihat hubungan antara filsafat Eckhart dengan panteisme. Eckhart mencoba menghubungkan antara eksistensi dunia dengan Ada Allah, kendati disadari tidak mungkin menyematkan atribut apapun pada Allah di dalam aktivitas temporer. Albertus Magnus, guru Eckhart, sebelumnya pernah mengulangi rumusan yang sangat padat-berisi ini: God created all things from eternity, but things were not created from eternity. ${ }^{51} \mathrm{Na}$ mun, Eckhart secara lebih radikal menyatakan bahwa harus diakui jika dunia (ciptaan) adalah berasal dari kekekalan, karena mengacu pada dinamika Trinitas sebagai genesis yang a-temporal, kemajuan dunia di dalam dunia nyata maupun dunia ide.

Keidentikkan ciptaan dengan Allah inilah yang menimbulkan "kesan bahwa Segala Sesuatu adalah Allah." Kecurigaan dan bahkan tuduhan panteis, misalnya dilontarkan oleh H. von Virneburg, Uskup Agung Köln, dialamatkan pada pemikiran Eckhart. Padahal

50 Pokok ini disarikan dari khotbah Meister Eckhart, "Deus Unus Est" atas Galatia 3: 16-22 dalam Meister Eckhart: Selected Treatise and Sermons, (London: HarperCollins Publisher, 1994), 179-183. Selain itu, "all creatures are one with God" (Sermons LW XXIX, dikutip dari Meister Eckhart. Selected Writings, (Introd. by Oliver F. Davies), London etc.: Penguin Books, 1994).

51 Rumusan yang digemari oleh Albertus Agung dalam komentar atas The Celestial Hierarchy karya Pseudo Dionysius, 4. Jiwa rumusan itu berdekatan dengan ungkapan Agustinus, "In the eternal word dost Thou speak eternal all that Thou speakest; and yet not all exist at once and from eternity that Thou ef fectest in speaking." (Confessiones, 11,7). Keterangan ini kami dapatkan dalam Frederick Copleston, A History of Philosophy: Late Medieval and Renaissance, Jilid 3, (London-New York: Continuum, (1953), 2003), hlm. 191. keserupaan antara Allah dan ciptaan (hanya) dialami dalam situasi yang amat khusus, yakni mistik, ketika keduanya "bukan lagi dua, melainkan satu”. Bahkan pandangan Agustinus dan para Skolastik tidak mudah memahami perspektif ini dan dinamika ini yang terus diperdalam. ${ }^{52}$

\section{Hubungan Jiwa Manusia dengan Allah}

Deity yang tidak terkualifikasi, Allah Trinitas, dan ciptaan adalah tiga dimensi realitas yang saling berurutan secara konseptual, namun tidak dalam pengertian temporal, apalagi kronologis. Semua ciptaan mengambil bagian dari esensi ilahi, namun jiwa yang sejati memiliki derajat yang lebih tinggi. Di dalam ciptaan yang irasional, misalnya hewan atau binatang, yang tidak mempunyai jiwa seperti manusia, ada "sesuatu" entah apa namanya yang berasal dari Allah. Di dalam manusia yang berjiwa terdapat dan terungkap ciri-ciri Allah sendiri. Itulah sebabnya, hanya ciptaan yang rasional, yakni manusia, sajalah yang mampu menerima Allah, Manusia yang memiliki jiwa itu bagaikan tempat Allah beristirahat dan bersemayam, dan di dalam jiwa manusia Allah sungguh-sungguh menjadi subjek, God is Subjective. Jadi, jika di dalam manusia yang berjiwa, Allah dapat "men-subjek", maka di dalam ciptaan lain yang tidak mempunyai jiwa Allah "meng-objek".

Jiwa adalah citra Allah, yang dituntun oleh kekuatan, ingatan, akal budi, kehendak yang selaras dengan pribadi ilahi, senada dengan pandangan Agustinus. ${ }^{53}$ Seperti Dei-

52 Baca B. McGinn, "The God beyond God: Theology and Mysticism in the Thought of Meister Eckhard", dalam Journal of Religion, Vol. 61, N. 1 (Jan. 1981): 1-19.

53 Tetapi jiwa yang rasional itu sesungguhnya tidak dapat benar-benar mengenal Allah. Sebab tidak ada konsep tentang Allah yang dapat berisi Allah. Paham manusia tentang Allah tidak pernah (memuat paham) Allah. Agustinus menegaskan, "If you comprehend it, it is not God." Lihat Augustine of Hippo, Tractates on the Gospel John, 38.10. (Transl. By John W. Rettig), Washington D.C.: The Catholic University of America Press, 1998. 
ty yang absolut yang bersifat superior terhadap pribadi-pribadi, begitu pula Ia berkuasa dalam jiwa yang dinamai Eckhart sebagai "percikan kecil" ilahi. Dari sinilah dapat dipahami bahwa basis jiwa dengan Deity adalah satu dan bersifat identik. ${ }^{54}$

Memang, di satu sisi dihayati bahwa jiwa beristirahat kekal dalam Deity, namun di sisi lain ia juga masuk ke dalam eksistensi temporal melalui rahmat. Hal ini tidak dianggap kontradiktif. Sebagai Ada yang Subyektif, Allah tetap menjadi prinsipnya dan tidak bersifat niscaya begitu saja. Ia tidak hanya mencipta tetapi sungguh datang dan masuk ke dalam ciptaan, kendati bukan berarti bebas hambatan. Hanya dalam (jiwa) Kristus, Ia bisa masuk secara sempurna, sementara ke dalam jiwa lain, Ia terhambat oleh sejumlah halangan, khususnya dosa.

\section{Dosa dan Penebusan}

Kecenderungan berdosa berasal dari keterbatasan yang menjadi konsekuensi kehendak bebas ciptaan. Jiwa manusia dimaksudkan menjadi tempat peristirahatan Allah. Mengikuti kehendak sendiri menuju sesuatu yang terbatas (dosa) menjadikan hal itu tidak mungkin terwujud. Namun, bagi Meister Eckhart, tidak ada satu pun dalam keterbatasan yang tidak dapat disingkirkan dari jiwa (termasuk dosa dan kematian) dan hal itu dimungkinkan oleh penebusan. Hal ini hanya mungkin terjadi ketika ciptaan memberi ruang dalam jiwa untuk pekerjaan Allah, dimulai dengan berbalik dari hal-hal yang terbatas. Oleh karena itu, pemisahan diri secara internal dengan hal-hal yang profan, indrawi, duniawi akan memungkinkan

54 Pokok pikiran mengenai relasi jiwa manusia dengan Allah dalam Eckhart kita temukan dalam karya-karya yang mengomentari karya Eckhart, misalnya Ursula Fleming, The Man From Whom God Hid Nothing, (Leominster: Gracewing, 1995); Bernard McGinn, The Mistical Thought of Meister Eckhart: The Man rom Whom God Hid Nothing, (New York: Crossroads Herder, 2001). pekerjaan Allah di dalam hati terlaksana. Hal inilah yang disebut Eckhart sebagai "Abegescheidenheit" (atau detachment). ${ }^{55}$ Dalam berbagai khotbah dan ajaran spiritualnya, Eckhart menegaskan demikian:

"When I preach, I usually speak of detachment and say that a man should be empty of self and all things; and secondly, that he should be reconstructed in the simple good that God is; and thirdly, that he should consider the great aristocracy which God has set up in the soul, such that by means of it man may wonderfully attain to God; and fourthly, of the purity of the divine nature." ${ }^{56}$

Inkarnasi ${ }^{57}$ Allah dalam hal ini menghilangkan dualisme antara kedirian dengan Allah (Allah dengan manusia). Allah sungguh hadir dalam inti jiwa dan menunggu jiwa untuk melakukan Abegeschiedenheit, ${ }^{58}$ sehingga masuk ke dalam kesadaran. Disebutkan demikian;

"The person who wants to go to our Lord ... must first make sure that his conscience is without reproach. In the second place, his will must point only to God and he must so concentrate on God that he can take

55 John Orme Mills OP dari The Eckhart Society pada 18 Maret 2000 berbicara tentang "Being Detached" dalam pengertian Eckhart. la menyatakan bahwa detachment is a supreme virtue, the virtue which in fact comprehends all the other virtues - even faith and love and humility. Lihat https://www.eckhartsociety.org/resources/meister-eckhart-and-prayer-talk-2-being-detached. Selain itu, pemikiran tentang detachment yang berarti breaking through, take leave of yourself, depart from ourselves ditemukan dalam Sermon 80. Lihat http://www. documentacatholicaomnia.eu/03d/1260-1328,_Eckhart,_Sermons,_EN.pdf.

56 Marcus Braybrooke, Beacons of Light: 100 People Who Have Shaped the History of Humankind, (Oxford: O Books, 2009), 316-317.

57 Ditilik maknanya, istilah "inkarnasi" di sini bukan dalam arti penjelmaan Allah menjadi manusia di dalam Yesus yang dijadikan Kristus, melainkan inkarnasi dalam matra mistik, di mana jiwa abadi berada dalam suasana surgawi. Lihat studi menarik Niklaus Largier, "Interpreting Eckhart's Incarnation Theology: The Sermon Collection Paradisus anime intelligentis, dalam Eckhart Review, Vol. 13 (2004): 25-36.

58 Lihat penjelasan pada Catatan Kaki 54. 
pleasure in nothing but God... This is the test by which one may prove how far away from God one is-or how near-according as one is less or more this way.... For we are to be changed into Him and made One with Him, so that what is His shall be ours and what is ours, His: our heart and His are to be one heart; our body and his, one body. So, too, it shall be with our senses, wills, thoughts, faculties, and members: they are all to be transported into Him, so that we feel with Him and are made aware of Him in every part of body and soul.... His is the only treasure with which you will be contented or satisfied. ${ }^{59}$

Sejumlah pengamat mencoba melihat "skema" perkembangan mistik Eckhart yang banyak ditemukan dalam pandangan aneka mistisi Abad Pertengahan tentang tahapan pengalaman mistik, yakni fase pemurnian, penerangan, dan persatuan dengan Allah. Namun, bagi Eckhart, fase-fase itu dapat dilalui secara unik dan lebih terperinci, dengan kekhasan pengalaman setiap mistikus yang berbeda-beda.

Eckhart sesungguhnya selalu menekankan, jalan spiritual justru ditempuh melalui "jalan yang tak berjalan" (wayless way) ${ }^{60}$ dengan ketiadaan metodologi murni yang partikular dan bentuk kontemplasi tertentu menyangkut Kebenaran Ilahi yang sederhana. ${ }^{61}$ Kendati demikian, Eckhart sendiri menyadari, peleburan sempurna antara jiwa dengan Deity tidak pernah terjadi. Pandangan ini yang kiranya menjadi perspektif Eck-

59 Meister Eckhart, Talks of Instruction XX, James M. Clark, Meister Eckhart, 73-77.

60 Christopher M. Knauf, Meister Eckhart and the "Wayless Way", dalam https://lifeisthismoment.com/2014/05/19/meistereckhart-and-the-wayless-way. Diunduh 1 Juni 2020.

61 "All people are not called to God by the same road, as St. Paul says.... (TI XVII) Let a person choose one good way [of meditation, prayer, etc.] for himself and stick to it... We must see that all good ways belong together in the One Way." (TI XXII) hart untuk melawan konsep Apokatastasis ${ }^{62}$ yang mungkin saja menjadi ekses niscaya dari kesatuan manusia dan Allah, sehingga pada akhirnya tidak ada manusia yang masuk dalam neraka dan binasa.

Mengenai pandangan Kristologinya, ${ }^{63}$ Eckhart pertama-tama melihat permasalahan dosa bukanlah sebab utama dari inkarnasi. Allah menghendaki kodrat ciptaan melalui rahmat di dalam waktu bukan di dalam kekekalan diri-Nya. Manusia menduduki posisi sentral dalam dunia ciptaan, memimpin seluruh ciptaan untuk kembali kepada Allah. Senada dengan Maximus Confesor dan Yohanes Scotus Eriugena, Kristus dihayati sebagai pusat dari kemanusiaan.

Mengingat ke-dosa-an manusia, Kristus berdiri sebagai pusat penebusan. Jatuhnya manusia ke dalam dosa, mendorong semua ciptaan baik yang berjiwa maupun yang tidak, baik yang rational maupun tidak, merindukan suatu harmoni kebaikan, yang dalam ajaran Gereja hanya digenapi oleh

62 Apokatastasis merupakan konsep pemikiran atau ajaran lama yang dipopulerkan kembali oleh Origenes. Konsep atau ajaran itu menyatakan bahwa pada akhirnya semua ciptaan yang bermoral bebas seperti malaikat, manusia, setan akan menerima rahmat keselamatan abadi. Konsep pemikiran ini didasarkan pada interpretasi atas Kis. 3:19-21. Lihat Origen, On First Prin ciples, Ed. G.W. Butterworth, (New York: Harper \& Row, 1966), I.IV,2 yang menyatakan sebagai berikut, "For the end is always like the beginning: as therefore there is one end of all things, so as there is one end of many things, so from one beginning arise many differences and varieties, which in their turn are restored, through God's goodness, through their subjection to Christ and their unity with the Holy Spirit, to one end which is like the beginning." Konteks umum pandangan Origenes ini diutarakan a.I. oleh Joseph W. Trigg, Origen, (London \& New York: Routledge, 1998), 30.

63 Beberapa studi tentang kristologi Meister Eckhart telah dilakukan, misalnya Richard Schneider, "The Functional Christology of Meister Eckhart", dalam Recherches de théologie ancienne et médiévale 35 (1968): 291-322; Nicholas Collura, "Seeing All Things as Noting": Meister Eckhart and the Incarnation", dalam Lumen et Vita, Vol. 35 (Juillet-Décembré 2013): 1-10, terutama halaman 5-6; David H. Jensen, Christian Understandings of Christ: The Historical Trajectory, (Minneapolis: Fortress Press, 2019), 126-230; Satoshi Kikuchi, "Christological Problem in the Understanding of the Sonship in Meister Eckhart," dalam Bijdragen: Tijdschrift voor Filosophie en Theologie, vol. 69 (4, 2008): 365-381 ; E.-H. Wéber, "Le Christ selon Maître Eckhart", dalam K. Emery - J.P. Wawrykow (eds), Christ among the Medieval Dominicans, (Notre Dame: University of Notre Dame Press, 1998), 414-429. 
campur tangan Allah Yang Mahabaik. ${ }^{64} \mathrm{Hal}$ inilah yang akhirnya terjadi ketika Maria terbebas dari kehendaknya sendiri secara sempurna dan menjalankan sabda ilahi yang memulihkan kodrat manusia. Jadi, dalam momen kelahiran temporal Putra pun sesungguhnya juga terjadi kelahiran abadi pada momen yang sama, Allah sungguh lahir dalam manusia. Yesus menjadi patron dalam kehidupan manusia, sehingga apapun yang Ia lakukan dan alami, bahkan melampaui peristiwa sengsara dan kematian telah mengangkat martabat manusia "setara" dengan Allah dan menunjukkan bahwasanya Kristus sungguh menjadi jalan menuju Bapa.

\section{Etika $^{65}$}

Kualitas pengalaman mistik bisa diukur dari buah kontemplasi, terutama peningkatan sukacita, amal kasih dan spirit menjalani kehidupan. Jadi, selain bermakna teologis, mistik amat berhubungan dengan aspek kebajikan dan juga moral. Bagi Eckhart, dimensi internal (batiniah) dalam (jiwa) manusia merupakan hal utama. Dalam seruan-seruannya, Eckhart menekankan bahwa di dalam batinlah, manusia perlu kembali kepada Allah dan membiarkan diri dipimpin oleh-Nya. Relasi intim ini tidak terjadi karena hal-hal besar dan suci yang dilakukan manusia untuk menyerupai Kristus. Namun, Allah sungguh memberikan diri pada setiap orang; dan Ia tinggal di dalam dan dengan cara-Nya sendiri. Dituliskan demikian:

"Love knows nothing of sin-not that man has not sinned—but sins are blotted out at

64 Lihat Mary Beth Ingham, The Harmony of Goodness, (New York: Franciscan Institute Publications, 2013), yang dalam praktiknya harmoni kebaikan itu berkenaan dengan kristologi etis, yang akan dibicarakan di bawah 3.2.5 berikut ini.

65 Oliver Davies, "Meister Eckhart's Ethical Universalism, Confucianisme, and the Future of Christianity: Eckhart and Confucianism", Journal of Chinese Philosophy, Vol. 41 (December 2014): 615-668. once by love and they vanish as if they had not been. This is because whatever God does he does completely, like the cup running over. Whom he forgives, he forgives utterly and at once." 66

Eckhart melihat, manusia sesungguhnya tidak perlu lari dari dunia, melainkan ia perlu lari dari kedirian, kehendak egonya, dan mengalami detachment (Abegescheidenheit). Dalam beberapa tulisan diungkapan bahwa penderitaan merupakan cara yang paling efektif dan bernilai untuk sampai ke tahap itu. Ia menyadari, amatlah wajar dipengaruhi oleh berbagai kesenangan, tetapi di dalam jiwa yang terdalam, tetap harus berpegang pada Allah dan membiarkan dirinya digerakkan oleh ketiadaan. Untuk sampai di sana, Eckhart memandang pekerjaan amal kasih amatlah bernilai, khususnya pada mereka yang miskin. Oleh karena itu, Eckhart menempatkan Martha lebih tinggi dari Maria. ${ }^{67}$ Sementara Maria menikmati kemanisan Allah, Martha dianggapnya telah melalui tahap itu. Pekerjaan tidak menghalanginya mengenal Tuhan tetapi justru membantunya masuk dalam suasana terberkati. Etika sesungguhnya sudah hidup, hadir dan berdinamika di dalam inti ADA yang satu. Indikatornya, kontemplasi yang sungguh spiritual niscaya mengalir dalam tindakan kasih (serupa dengan Allah), sehingga kontemplasi-aksi tidak dapat dipisahkan dan merupakan satu proses yang dinamis.

66 Meister Eckhart, Talks of Instruction XV, James M. Clark, cs (Penerj.), Meister Eckhart, 66-67.

67 Dalam Sermon 2 dan Sermon 86 Eckhart memperlihatkan keunggulan Martha tersebut, yang digambarkan "a virgin who is also a wife." Di dalam ulasan tentang Lukas 10:38 berdasarkan Sermon tersebut Amy Hollywood menyatakan: "There Martha is described as the wifely virgin soul, one who is fully detached and unified with the divine ground without distinction and is necessary active in that she shares in the divine work of the self-generation of the son. The soul as virgin and wife shares in the one work of the divine, which is the birth of justice." Amy Hollywood, "Preaching as Social Justice in Meister Eckhart," dalam Janet K. Ruffing (ed), Mysticism and Social Transformation, (New York: Syracuse University Press, 2001), 80. 
There can be no good man who does not want what God wants, because it is not possible that God should want anything but goodness, and just because of this, when God does want something, it must be not only for the good but for the best. That is why our Lord has taught us, through the apostles, to pray every day [in the Our Father] that God's will be done. And yet, when the will of God is done, we complain and are sad and troubled.... It is impossible that God should let adversity befall anyone, except he intended to spare that person much greater, or to prepare him for a nobler earthly comfort, or he intended something better to come of it.... ${ }^{68}$

Dalam refleksi selanjutnya tentang penyangkalan diri dan pemaknaan momen penderitaan, pandangan Eckhart sesungguhnya amat alkitabiah. Dalam Injil disabdakan: "Setiap orang yang mau mengikut Aku, ia harus menyangkal dirinya, memikul salibnya dan mengikut Aku" (Mat. 8:34). Jika setiap orang sungguh menyangkal dirinya, sesungguhnya tidak pernah ada penderitaan dan rasa sakit dalam penyaliban. Bagi mereka, justru kebahagiaan, sukacita dan kepenuhan jiwa bagi mereka yang sungguh mengikuti Allah.

\section{TANGGAPAN KRITIS DAN KESIMPULAN}

\section{Tanggapan Kritis}

Bertolak dari beberapa pemaparan pemikiran Eckhart dan kajiannya, kami juga menyimak beberapa poin kontroversi yang menyertai pemikiran Eckhart. Memang, keunikan pemikiran Eckhart yang menjadi "anomali" dalam Sekolah Dominikan. Mengingat Eckhart mengedepankan pokok

68 Meister Eckhart, Divine Consolation II James M. Clark, cs. (Transl.), Meister Eckhart, 94-122. pemikiran Neoplatonis, yang berbeda dengan pandangan Thomistik, konsep sentral Dominikan dan Skolastik Barat yang cenderung Aristotelian, maka hal itu menimbulkan sejumlah pertanyaan. Namun, kami melihat setidaknya ada tiga pokok ini yang menjadi serangan/gugatan utama terhadap pandangan Eckhart, baik dari Gereja (Katolik Roma) maupun kaum "penjunjung" ortodoksi Gereja yang merasa "terlukai" oleh pandangan Eckhart. Berikut ini akan disarikan pokok tersebut:

Pertama, Eckhart dianggap sebagai penentang "ortodoksi", yakni penggugat doktrin Gereja, khususnya mengenai konsep tentang Allah. Tuduhan ini diberikan karena Eckhart dianggap lebih menekankan "Allah tak bernama" melampaui "Allah doktrin" yang diajarkan Gereja. Dalam berbagai tulisan, sesungguhnya Eckhart amat menghormati doktrin yang dipegang teguh Gereja. Contoh paling nyata adalah pandangannya tentang Trinitas. Ia merefleksikan lebih dalam iman Gereja dengan pengalaman (mistik) personal yang melihat dinamika manifestasi Allah dalam tiga pribadi ilahi (Bapa, Putra, Roh Kudus). Hal ini jelas menunjukkan kesetiaanya memperdalam pemaknaan doktrin iman Gereja dalam pendekatan yang kaya (fides querens intellectum). Saat tuduhan heresi dialamatkan padanya, ia dengan setia mempertanggungjawabkannya di hadapan Takhta Suci, kendati gagal karena beliau wafat sebelum mewujudkannya.

Kedua, Eckhart dituduh menjadi pendukung panteisme yang memandang segala sesuatu (dalam realitas ciptaan) sebagai Allah (Ilahi). Jika dilihat sepintas, pandangan Eckhart memang rentan ditafsirkan demikian, namun ia sesungguhnya menekankan persatuan (keiidentikan) antara ciptaan dengan Allah itu hanya terjadi dalam situasi 
yang amat khusus, yakni pengalaman mistik. Pada kesempatan itu, manusia sungguh menanggalkan segala kediriannya sehingga tidak tersisa apapun kecuali Allah. Terjadi kesatuan substansial dengan ketiadaan dikotomi antara keduanya. Selain itu, perspektifnya juga tidak jatuh pada upaya pengultusan segala sesuatu (materialisme) yang malah mengarah ke konsep Allah yang plural (banyak bentuk). Tuduhan ini diakui merupakan ekses tafsiran dari para simpatisan Eckhart yang bertolak dari pandangan kebaikan segala sesuatu karena Allah Mahabaik adanya. Pandangan netral ini banyak ditafsirkan banyak pengikutnya untuk menghayati "kebebasan gerak Roh" yang mengarah pada praktik hidup rohani yang non-etis dan immoral dengan praktik "perkawinan rohaninya”, misalnya yang dilakukan oleh kelompok Free Spirit (salah satu kelompok kontemplatif yang cara hidupnya diinspirasikan oleh pemikiran Eckhart).

Ketiga, pandangan Eckhart dan arahan spiritual yang dijalankannya bisa dianggap mengarah kepada praktik quietisme atau semi-quietisme, yakni suatu aliran kontemplatif yang menekankan secara mutlak kepasifan manusia dalam pengalaman mistik tanpa sedikitpun peran manusia dan segala upaya lahiriahnya. Istilah Quietisme dapat dipahami sebagai doktrin yang menyatakan, kesempurnaan tertinggi manusia tercapai dalam penyangkalan diri secara fisik sebagai konsekuensi dari peresapan jiwa di dalam esensi Ilahi. Dalam hal ini jiwa secara menyeluruh tidak aktif, tanpa pikiran maupun kehendak personal, yang yang seringkali menjadi pokok kontroversi. ${ }^{69} \mathrm{Da}-$ lam pembacaan lebih lanjut, sesungguhnya Eckhart menekankan perlunya persiapan

69 Hal ini disarikan dari Tim New Advent Catholic Encyclopedia, Entri "Quietisme" diunduh dari http://www.newadvent.org/ cathen/14621 a.htm pada 27 Februari 2018, pk. 20.20 WIB. "aktif" manusia untuk melepaskan kelekatannya pada unsur duniawi melalui Abegeschiedenheit (detachment) menuju kemurnian nurani yang melancarkan jiwa untuk bersatu dengan Allah. Secara "metodis", ia mengajarkan beberapa tahapan doa dan askese untuk sampai kepada pengalaman mistik tersebut. Kendati demikian, keyakinan bahwa pengalaman akan Allah merupakan suatu anugerah tak pernah dibaikan pula.

Di luar semua kontroversi itu, Eckhart memberikan kontribusi sangat penting dalam khazanah pemikiran Abad Pertengahan. Di samping segala kontroversinya, tidak dapat dipungkiri pula bahwa pemikiran Ekchart telah menginspirasikan pengembangannya pada aneka pemikiran para tokoh penting di masa selanjutnya (Martin Luther, Henry Suso, Martin Heidegger, Karl Marx, Friedrich Hegel, Arthur Schopenhauer). ${ }^{70}$ Sebagai seorang mistikus yang menggunakan "jargon dan ragam bahasa yang terang dan tidak berbelit-belit", pemikiran Eckhart mudah menimbulkan multi tafsir, dan bahkan salah tafsir. Namun bagi Eckhart, segala sesuatu selalu muncul dari suatu yang sederhana, yakni pengalaman mistik yang personal yang coba "dinamainya". Bagaimanapun ia berjasa mengembangkan bahasa rakyat (khususnya Jerman) yang melahirkan berbagai istilah abstraksi penting di zamannya.

Penekanannya pada pengalaman rohani yang personal dan menyentuh menjadi alasan yang penting dalam praktik hidup beriman untuk mengalami sendiri Allah dalam tataran yang mendalam dan men-subyek

\footnotetext{
70 Bahkan Matthew Fox membuka dan mempertemukan celah bagi perjumpaan dengan pelbagai tokoh yang seakan di luar bidang yang selama ini diperhitungkan. Sebab pemikiran Eckhart itu menjadi inspirasi dan nasihat di bidang sosial, ekonomi, keadilan gender, dialog antaragama, bahkan praksis perjumpaan metaforis antartokoh, seperti Teilhard de Chardin, Thich Nhat Hanh, Carl G. Jung, Black Elk, Rumi, dan Adrianne Rich. Lihat M. Fox, Meister Eckhart: A Mystic Warrior for Our Time, (Novato, CA.: New World Library, 2014).
} 
(ortopraksis), serta tidak puas begitu saja puas akan "konsep" Allah-doktrin (ortodoksi) yang seringkali diterima begitu saja sebagai teori belaka. Namun, prioritas praksis juga tidak berarti bahwa teologi dimengerti melulu sebagai pembenaran saja atas praksis yang sudah dihidupi. Keduanya menjalankan peran penting dalam usaha untuk mempertajam refleksi agar sampai pada penghayatan dan praksis hidup beriman yang sehat dan berkualitas.

\section{Kesimpulan: Meister Eckhart Itu Penggugat atau Penguat?}

Meister Eckhart adalah salah satu tokoh penting teologi Abad Pertengahan, khususnya menyangkut teologi mistik. Dalam sekian banyak karyanya, dapat dijumpai pokok-pokok penting pandangan Eckhart, terutama menyangkut kesatuan antara Allah dengan ciptaan, khususnya manusia yang memiliki jiwa-rasional. Penghayatan ini dilandasi pada pengertian Eckhart akan "Allah yang tak bernama", tidak terkualifikasi dengan standar apapun yang disepadankan dalam tataran ciptaan. "Pengertian terbuka" tentang Allah ini membuatnya tidak berhenti pada penghayatan iman-dogma yang ditawarkan agama dan teologi, tetapi mempertajamnya dengan pengalaman (pribadi) persatuan dengan Allah sendiri, secara khusus dalam pengalaman mistik. Pengalaman Eckhart memperlihatkan, bahwa dari dirinya sendiri tidak ada sama sekali yang bisa menjadi jaminan tentang autensitas pengalaman mistis itu pasti sejalan dengan ajaran institusi Gereja, kecuali wujud nyata dari kata kunci ini Abegeschiedenheit: a supreme virtue, the virtue which in fact comprehends all the other virtues - even faith and love and humility; breaking through, take leave of yoursef, depart from ourselves. Sebab, kerendahan hati dapat dimiliki tanpa
Abegeschiedenheit, tetapi Abegeschiedenheit tidak dapat dimiliki tanpa kerendahan hati. Jadi. dari perspektif insani, langkah-langkah menuju kedalaman, kebeningan, kebersihan di dalam kesatuan mistik itu hanya dapat dimulai dari latihan rohani.

Bagaimanapun pengalaman mistik merupakan rahmat Allah sendiri yang disambut dengan upaya manusia melepaskan segala atribut, konsep dan pemikiran dan ego untuk menerima Allah sebagaimana adanya. Tidak berhenti sampai di sana, pengalaman mendalam itu tentunya juga mendorong praktik hidup yang baik (moral), berkeutamaan dan etis untuk menciptakan situasi yang kondusif untuk menerima Allah agar layak beristirahat di dalam batin.

Kendati tidak ada rumusan baku mengenai fase pengalaman mistik, berbagai tokoh yang mempelajari dan melestarikan pemikiran Eckhart seperti Richard J. Woods, Bernard McGinn, Ursula Fleming, Matthew Fox, Maurice O'C. Walshe, mencoba merumuskan beberapa fase pengalaman mistik yang dimaksud Eckhart. Dalam pemikiran mistiknya, dapat disimpulkan setiaknya ada 4 (empat) tahap dari persatuan antara Jiwa dan Allah, yakni ketidaksamaan, kesamaan, identitas, penerobosan. ${ }^{71}$ Hal ini menjadi landasan untuk memahami pandangan (sekaligus kontroversinya) yang menyatakan, God is all, the creature is nothing; at the ultimate stage. Daya dorong dari proses ini adalah pelepasan. Pokok-pokok ini disarikan dari karya khotbah Eckhart, yang dihimpun dan diterjemahkan oleh Maurice O'C. Walshe, ${ }^{72}$ khususnya Commentaries on the Bible, yang diuraikan sebagai berikut:

71 Disarikan dari Reiner Schürmann, "Meister Eckhart: German mystic" Encyclopedia Britannica Online, diunduh dari https:// www.britannica.com/biography/Meister-Eckhart, diunduh pada 20 Maret 2018, pk. 21.30 WIB.

72 Lihat The Complete Mystical Works of Meister Eckhard. Transl. and Ed. by Maurice O'C. Walshe, (New York: Crossroad, 2007). 
1. Ketidakserupaan (dissimilarity): Segala ciptaan adalah ketiadaan murni. Allah secara inheren memiliki keberadaan (being), sementara ciptaan hanya menerimanya secara turunan (derivasi). Jadi, di luar Allah, yang ada hanyalah ketiadaan. Manusia yang luhur tahu bahwa mereka bukanlah apa-apa pada diri mereka sendiri dan sadar bahwa mereka (adalah) sepenuhnya Allah.

2. Keserupaan (similarity): Manusia melepaskan diri dari hal-hal partikular/individual dan mengacu pada yang universal (Being), menemukan dirinya sebagai citra Allah dalam kemiripan dengan-Nya (asimilasi), sebagai anak, gambaran Bapa yang terpisah dari jiwanya. Manusia ada di dalam Dia bukan di dalam dirinya sendiri.

3. Identitas (identity): Manusia tidak pernah memiliki identitas substansial di dalam jiwa, namun tindakan Allah dan hal-menjadinya-manusia dipandang sebagai satu (God's operation and man's becoming are considered as one). Allah tidak lagi berada di luar manusia tetapi sungguh ada di dalamnya (interioritas). Ada (being) dan kodrat Allah satu. Yesus masuk ke dalam istana jiwa, percikan-Nya melampaui ruang dan waktu, cahaya jiwa itu tidak diciptakan. Ia sepenuhnya milik Allah tanpa perantara. Pusat Allah dan pusat jiwa adalah satu.

4. Penerobosan (breakthrough): Keserupaan identitas manusia dengan Allah belumlah cukup. Meninggalkan segala sesuatu tanpa meninggalkan Allah berarti (tetap) belum meninggalkan apapun. Manusia harus hidup "tanpa mengapa"73

73 Lihat John M. Connolly, Living Without Why: Meister Eckhart Critique of the Medieval Concept of Will, (Oxford: Oxford University Press, 2014); bdk. karya dalam bentuk audio Living Without A Why: Meister Eckhart's Mysticism. (Charlotte Radler). Loyola Marymont University, 2010. dan tidak harus mencari apa-apa, bahkan Allah sekalipun. Perspektif ini membawa manusia ke padang gurun, berhadapan dengan Allah. Bagi Meister Eckhart, Allah hadir sebagai "allah" hanya jika sesuatu yang melampaui "Allah" (Yang diyakini sebagai Pencipta). Allah (God) dan Ketuhanan (Deity) jelas berbeda. Pelepasan (diri) mencapai puncaknya dalam terobosan untuk mencapai sesuatu yang melampaui "Allah". Jika dipahami dengan benar, gagasan ini benar-benar bernilai Kristiani: ia merombak, untuk orang percaya, jalan "Salib" Kristus. ${ }^{74}$

Richard Wood yang kemudian dipertegas oleh Bernard McGinn menyebut Eckhart sebagai seorang Katolik yang loyal dengan ajaran yang amat ortodoks secara keseluruhan. ${ }^{75}$ Selanjutnya, Karl G. Kertz menyatakan ajaran Eckhart mengenai kelahiran Allah di dalam jiwa merupakan ajaran Katolik yang "sehat sekali". Berbagai analisis menyatakan, pandangan Eckhart "dikutuk" sesungguhnya bukan karena gagasannya tidak ortodoks (menolak konsep atau doktrin Gereja), bukan pula karena korban politik Gerejawi semata. Wood menggambarkan kontroversi ini dengan menempatkan Eckhart sebagai "seniman", sementara melihat para penggugat dan pendakwanya sebagai "birokrat-birokrat" yang mempertahankan doktrin sebagai arah dasar iman Gereja. Eckhart mengungkapkan pengalaman rohani-mistik yang mendalam bagaikan puisi yang tidak mudah mereka pahami, sehingga ekses dan lambungan imajinasi yang melampaui garis-

\footnotetext{
74 Kata "Salib" kami tambahkan, mengingat Eckhart hampir pasti tidak membicarakannya secara khusus. Kami hanya dapat menduga, bahwa SALIB memiliki makna dalam hidup Eckhart, tetapi bagaimana persisnya: Mengapa beliau tidak menaruh perhatian pada SALIB dalam karyanya, kami tidak bisa memastikan. Untuk lebih meyakinkan lagi, kiranya tema SALIB dalam karya Eckhart dapat menjadi bahan penelitian lain waktu.

75 Richard J. Woods, Eckhart's Way, (Dublin: Veritas, 2010), 212 213.
} 
garis besar risalah dan debat ilmiah yang kering dirasa "menggoyang" kewibawaan dan stabilitas yang ada. ${ }^{76}$

Selain itu, Eckhart digambarkan sebagai sosok "progresif" yang dianggap menjadi pelopor diskursus dengan iman kepercayaan lain, misalnya Buddhis-Kristiani yang melihat banyak unsur yang senada antara ajaran Kristen (Eckhart) dengan Zen. Selain itu, pemikirannya banyak dikembangkan oleh para pengikutnya (H. Suso hingga M. Luther yang menafsirkan "anti-dogmatis Eckhart" sebagai pelecut gerakan reformasi dalam Gereja dan seterusnya). Eckhart seringkali dijuluki "Galileo dari para mistikus" yang dihukum walaupun sesungguhnya menyuarakan kebenaran ortodoks pula untuk memahami Injil Kristus secara mistik. Apapun juga, penilaian Eckhart sebagai penggugat atau penguat refleksi teologis Gereja amat terbuka untuk dipikirkan dan diteliti dengan saksama.

Kiranya pandangan dan keyakinan Eckhart ini tidak berlebihan: Beliau memang dapat salah dalam usaha memaparkan pandangan teologis, ajaran, dan praktis, akan tetapi ia samasekali bukan seorang heretik. Dengan standar dan patokan kekristenan Avignon abad XIII-XIV memang ia heretik sebagaimana diperlihatkan oleh bulla In agro dominico, 27 Maret 1329. Dengan konsisten beliau menekankan kesatuan Allah dan kemampuan jiwa setiap pribadi untuk menjadi satu dengan Allah selama hidupnya. Baginya, jiwa manusia yang dilengkapi oleh Allah dengan kodrat rasional lebih unggul di mata Eckhart daripada malaikat sekalipun. Beliau memperkenalkan makna dan kedalaman arti Abegeschiedenheit (detachment) dengan istilah populer, yakni pergi, keluar untuk melampaui diri demi menjumpai Allah pada dasar diri yang paling bersahaja, pada suatu belantara yang hening dan bening tanpa pembedaan. Di luar kodrat dan esensi itu yang ada hanyalah ciptaan. Oleh karena itu, dapat dimengerti jika Yohanes Paulus II merehabilitasi Meister Eckhart dari kecaman yang berasal dari perbedaan ajaran dan pandangan. $* * * *$

$\overline{76}$ Richard J. Woods, Eckhart's Way, (Dublin: Veritas, 2020), 215. 


\section{DAFTAR RUJUKAN}

Abbrescia, A.-G. della Croce. Art. "Govanni Eckhart". In Dizionario enciclopedico di spiritualità/2. (A cura di Ermando Ancilli e del Pontificio Istituto di Spiritualità del Teresianum). Nuova edizione completamente aggiornata e ampliata. Roma: Città Nuova Editrice, 1990, pp. 858-862.

Braybrooke, M. Beacons of Light: 100 People Who Have Shaped the History of Humankind. Oxford: O Books, 2009.

Calati, B.-R. Grégoire - A. Blasucci. La spiritualità del Medioevo. Storia della spiritualità, vol. 4. (Introduzione di Gennaro Bove). Roma: Borla, 1988, pp. 352-356.

Clark, J.M. cs. (Transl.). Meister Eckhart: Selected Treatise and Sermons. London: HarperCollins Publisher, 1994.

Collura, N. "Seeing All Things as Noting": Meister Eckhart and the Incarnation." In $\mathrm{Lu}$ men et Vita, Vol. 35 (Juillet-Décembré 2013): 1-10.

Connolly, J.M. Living Without Why: Meister Eckhart Critique of the Medieval Concept of Will. Oxford: Oxford University Press, 2014.

Copleston, F. A History of Philosophy: Late Medieval and Renaissance. Jilid 3. London-New York: Continuum, (1953), 2003.

Crouzel, H. Origen. Translated by A.S. Worrall. Edinburgh: T.\&T. Clark, 1998.

Davies, O. "Meister Eckhart's Ethical Universalism, Confucianisme, and the Future of Christianity: Eckhart and Confucianism." In Journal of Chinese Philosophy. Vol. 41 (December 2014): 615-668.

Dombrowski, D.A. St. John of the Cross: An Appreciation. New York: State University of New York Press, 1992.

Eddy Kristiyanto, A. Reformasi dari Dalam. Sejarah Gereja Zaman Modern. Yogyakarta: Kanisius, 2004.

Eddy Kristiyanto, A. cs. Martin Luther: Musa Jerman. 5 Abad Reformasi Agama. Jakarta: OBOR-BPK Gunung Mulia, 2017.

Fleming, U. The Man From Whom God Hid Nothing. Leominster: Gracewing, 1995.
Fox, M. Meister Eckhart: A Mystic Warrior for Our Time. Novato, CA.: New World Library, 2014.

Francke, K. "Medieval German Mysticism". In The Harvard Theological Rieview, Vol. 9, No. 1 (Jan., 1912).

Grundmann, H. Religiöse Bewegungen im Mittelalter. Untersuchungen über die geschichtlichen Zusammenhänge zwischen der Ketzerei, den Bettelorden und der religiösen Frauenbewegung im 12. und 13. Jahrhundert und über die geschichtlichen Grundlagen der Deutschen Mystik. Darmstadt: Wissenschaftliche Buchgesellschaft, 1977.

Hart, R.L. God Being Nothing: Toward a Theogo$n y$. Chicago and London: The University of Chicago Press, 2016.

Hollywood, A. "Preaching as Social Justice in Meister Eckhart." Dalam Janet K. Ruffing (ed). Mysticism and Social Transformation. New York: Syracuse University Press, 2001.

Hollywood, A. (ed). Christian Mysticism. New York: Cambridge University Press, 2012.

Howells, E.-M.A. McIntosh (eds). The Oxford Handbook of Mystical Theology. Oxford: Oxford University Press, 2020.

Ingham, M.B. The Harmony of Goodness. New York: Franciscan Institute Publications, 2013.

Jensen, D.H. Christian Understandings of Christ: The Historical Trajectory. Minneapolis: Fortress Press, 2019.

Kelley, C.F. Meister Eckhart on Divine Knowledge. New Haven-London: Yale University Press, 1977.

Kikuchi, S. "Christological Problem in the Understanding of the Sonship in Meister Eckhart." In Bijdragen: Tijdschrift voor Filosophie en Theologie. Vol. 69 (4, 2008): 365-381.

Largier, N. "Interpreting Eckhart's Incarnation Theology: The Sermon Collection Paradisus anime intelligentis. In Eckhart Review. Vol. 13 (2004): 25-36. 
Lerner, R.E. The Heresy of the Free Spirit in the Later Middle Ages. Berkeley: University of California, 1972.

McGinn, B. The Essential Writings of Christian Mysticism. New York: Random House, 2006.

McGinn, B. The Presense of God: A History of Western Christian Mysticism. 7 Vols. New York: Crossroad, 1991-2017.

McGinn, B. "The God beyond God: Theology and Mysticism in the Thought of Meister Eckhard." In Journal of Religion. Vol. 61, N. 1 (Jan. 1981): 1-19.

McGinn, B. The Mystical Thought of Meister Eckhart: The Man from Whom God Hid Nothing. New York: The Crossroad Publishing Company, 2001.

McGinn, B. Meister Eckhart and the Beguine Mystics: Hadewijch of Brabant, Mechthild of Magdeburg, and Marguerite Porete. New York: Continuum, 2001.

McGinn, B. "The Dynamism of the Trinity in Bonaventure and Eckhart". In Franciscan Studies. 65 (2007):137-155.

McGinn, B. (ed). Meister Eckhart: The Essential Sermons, Commentaries, Treatises and Defence. New York: Paulist Press, 1981.

McColman, C. The Big Book of Christian Mysticism. Charlottesville, VA: Hampton Roads, 2010.

McIntosh, M.A. Mystical Theology: The Integrity of Spirituality and Theology. Maldon-Oxford: Blackwell, 1998.

Meister Eckhart. I sermoni latini. (Traduzione, introduzione e note a cura di Marco Vannini). Roma: Città Nuova Editrice, 1989.

Merton, Th. A Course in Christian Mysticism. Collegeville, MN.: Liturgical Press, 2017.

Milem, B. The Unspoken Word: Negative Theology in Meister Eckhart's German Sermons. Washington, D.C.: The Catholic University of America Press, 2002.

Nieuwenhove, R. van. An Introduction to Medieval Theology. Cambridge: Cambridge University Press, 2012.

Otten, W.-G. Lachance. "The Language of the Mystical Embrace: Desire and the body in Johannes Scotus Eriugena and Meister
Eckhart." In Les Études Philosophiques. 2013/1 (No. 104): 121-141.

Perl, E.D. Theophany: The Neoplatonic Philosophy of Dionysius the Areopagite. New York: State University of New York Press, 2007.

Reynolds, P.L "Bullitio and the God beyond God: Meister Eckhart's Trinitarian Theology. Part I: The Inner Life of God." In New Blackfriars. 70, N. 826 (April 1989): 169181.

"Bullitio" and the God beyond God: Meister Eckhart's Trinitarian Theology. Part II: Distinctionless Godhead and Trinitarian God." In New Blackfriars. 70, N. 827 (May 1989): 235-244.

Robino, Elisa. "Pseudo-Dionysius the Areopagite and Eckhart." In Jeremiah M. Hackett (ed). A Companion to Meister Eckhart. Leiden-Boston: Brill, 2013, 299-309.

Rolt, C.E. Dionysius the Areopagite On the D $i$ vine Names and the Mysticall Theology. New York: Casimo Classics, 2007.

Rosemann, P.W. The Story of A Great Medieval Book Peter Lombard's Sentences. Toronto: University of Toronto Press, 2007.

Schneider, R. "The Functional Christology of Meister Eckhart." In Recherches de théologie ancienne et médiévale. 35 (1968): 291 322.

Scorgie, G.G. cs. (eds). A Dictionary of Christian Spirituality. Michigan: Zondervan, 2011.

Sheldon-Williams, I.P. (ed). Johannis Scotti Eurigenae Periphysion: De divisione naturae. 3 Vols. Dublin: Dublin Institute for Advanced Studies, 1968-1981.

Simonetti, M. Biblical Interpretation in the Early Church. An Historical Introduction to Patristic Exegesis. (Transl. John A. Hughes). Edinburg: T\&T Clarck, 1994.

Swan, L. The Wisdom of the Beguines: The Forgotten Story of A Medieval Women's Movement. New York: BlueBridge, 2016.

Taylor, J. (Transl. and Introd.). The Didascalion of Hugh of Saint Victor: A Medieval Guide to the Art. New York: Columbia University Press, 1991.

Trigg, J.W. Origen. London \& New York: Routledge, 1998. 
Volpe, G.D. Il misticisme speculativo di Maestro Eckhart nei suoi rapporti storici. Bologna: il Mulino 1989.

Wakefield, S.G. (ed). A Dictionary of Christian Spirituality. Los Angeles, SCM Press Ltd., 1988.

Walshe, M.O'C. (Transl.). The Complete Mystical Works of Meister Eckhart. New York: A Herder \& Herder Book, 2009.

Wéber, E.-H. "Le Christ selon Maître Eckhart." In K. Emery-J.P. Wawrykow (eds). Christ among the Medieval Dominicans. Notre Dame: University of Notre Dame Press, 1998, 414-429.

Wendlinder, A. Speaking of God in Thomas Aquinas and Meister Eckhart: Beyond Analogy. Ashgate Publishing, 2014.

Woods, R.J. "Meister Eckhart and the Neoplatonic Heritage: The Thinker's Way to God." In The Thomist: A Speculative Quarterly Review. Vol 54, (N. 4, Oct. 1990): 609-639.

Woods, R.J. Eckhart's Way. Dublin: Veritas, 2010. 
